\title{
LAND FOR LOGISTICS: LOCATIONAL DYNAMICS, REAL ESTATE MARKETS AND POLITICAL REGULATION OF REGIONAL DISTRIBUTION COMPLEXES
}

\author{
MARKUS HESSE \\ Institut für Geographische Wissenschaften, Freie Univesität Berlin, Malteserstraße 74-100, 12249 Berlin, \\ Germany. E-mail: mhesse@zedat.fu-berlin.de
}

Received: August 2003

\begin{abstract}
Physical distribution, logistics and freight transport are currently being shaped by new technologies, corporate restructuring, and a changing market environment. Following the rapid growth of logistics, the demand for distribution facilities increases significantly. As a consequence, logistics real estate markets have emerged, shaping local development practices. By establishing distribution centres as single entities and integrated freight centres as agglomerations, they contribute to the formation of 'regional distribution complexes'. The paper aims to exemplify this interrelation with two case studies in Berlin-Brandenburg, Germany: first a publicly developed integrated freight centre, offering multi-modal transport access and logistics services, and second a dispersed logistics site off the regional beltway, developed with respect to market requirements only. The paper finds that rising locational competition contributes to accelerated land consumption and further dispersal. Speculative development and outsourcing of facilities are 'mobilising' not only goods flows but also logistics infrastructure. Both practices, originally developed in the USA and the UK, are now changing land markets in continental Europe and affect urban and regional development.
\end{abstract}

Key words: Freight transportation, distribution centres, locational dynamics, logistics real estate markets, policy and planning

\section{INTRODUCTION: THE NATURE AND THE LOCATION OF FREIGHT DISTRIBUTION}

This paper is concerned with the spatial dimension of logistics, particularly the location of distribution facilities, the corresponding political regulation of development, and the consequences of the upcoming submarket of logistics real estate for urban development. This research is both related to economic and transport geography, particularly with respect to freight transport and location issues. An institutional perspective on regional development (Amin 1999; Guy \& Henneberry 2002) is chosen in order to highlight the particular interrelation and interaction of land suppliers, users and intermediaries. The advantage of such an approach is to overcome traditional assumptions on corporate locational behaviour, mostly based on a catalogue of location factors that attract or deter firms settling somewhere (Chapman \& Walker 1991; Hayter 1997, pp. 5, 6). Empirical evidence suggests that regional development processes are more complex, locally embedded, and context dependent (Storper 1997, pp. 26, 39). Also, infrastructure provision, private investments and policy and planning are mingling in mechanisms of cumultive causation, 
creating interrelated processes of local growth. These are interpreted in a special way that places are becoming 'produced' (Storper \& Walker 1989, p. 70).

The core subject is physical distribution. It is defined as 'the range of activities involved in the movement of goods from point of production to final point of sale.' (McKinnon 1988, p. 133). It comprises transport services, logistics and warehousing services, wholesale and, in principle, the supply chain behind retail. These distributive services have experienced strong growth in Europe in the past, in contradiction with the decline of railways and inland waterways. Globalisation, economic growth and sectoral changes toward corporate services have played a major role for establishing a specialised distribution service economy (Marshall 1988; Dicken 2003, p. 471). As the demand for distribution is changing, so is the locational logic of corporate decision-making. Large-scale goods flows are directed through major gateways and hubs, mainly large ports and major airports, transportation corridors and more recently, newly emerging inland hubs (Hesse 2002; van Klink \& van den Berg 1998; De Ligt \& Wever 1998; Pellegram 2001). Transport growth, supply-chain transformation and rising competition among mainports make their activity space increasingly becoming 'stretched'. By such 'sub-harbourisation' (Allaert 1999, p. 3), main ports are reaching far beyond their vicinity and connect to more distant places of their hinterland. In metropolitan regions, logistics changes are associated with rising demand for new distribution centres and warehouses. Due to space and traffic requirements, those are increasingly established at sub or even exurban places (Glasmeier \& Kibler 1996, p. 145; McKinnon 1983; Riemers 1998). This locational preference is based upon an earlier pattern of decentralisation, mainly due to cheaper land resources of suburbia, compared with the urban core, and better access to transport arterials (Chinitz 1960; Vance 1970). More recently, the suburban drift of distribution relates to locational problems within cities: The flexible, 'fluid' pattern of contemporary logistics is likely to disrupt other urban functions, such as housing. Conversely, suburban sites offer the desired 'robust' environment for 24-hour operations.

\section{THE DISTRIBUTION CENTRE: TECHNOLOGICAL INNOVATION, SPATIAL IMPLICATIONS}

The emergence of a new real estate market that is specifically dedicated to warehousing and distribution land uses is associated with two developments: first, speaking quantitatively, the growth of logistics services in general propels the demand for more distribution space. Manufacturing and retail firms relied less on warehousing activities. Therefore, additional capacity is needed to accommodate consolidation and growth effects. Second, in more qualitative terms, logistics companies demand a new type of facility, different from the old warehouse: the distribution centre (DC). A DC represents a 'physical facility used to complete the process of product line adjustment in the exchange channel. Primary emphasis is placed upon product flow in contrast to storage.' (Bowersox et al. 1968, p. 246). It is no longer needed for storage but for the efficient consolidation of the materials flow. Despite the predominant 'flow orientation' of the modern economy, warehousing remains necessary in many events, particularly since it is hard to predict the demand for certain goods delivery. The more varied and differentiated the markets are becoming, the larger the market areas are, and the more competition is increasing, the more important is a finely tuned goods flow, mediated by buffers between suppliers and receivers of commodities. Thus, DCs are becoming key components in the supply chain.

Modern DC functions comprise receiving, storage, pick operations, value added activities, shippings, return processing, information management (Strauss-Wieder 2001, p. 10). One of the major tasks carried out in a DC is the consolidation of incoming freight and its immediate shipping to final destination (also known as 'cross-docking'). Storage is practised in certain commodity groups that may not be delivered within the short term. Added value is being pursued in post-production/pre-distribution processes, including assembly and customisation (labelling, assortment), packaging, ticketing or product return and repair. The size of DCs varies and depends on its role, the composition of the network, the size of the market area and the volume of transshipments. With the trend 
towards concentrated supply-chain functions and thus to a decreasing number of DCs, the average size of a facility is steadily increasing, simply following the law of economics of scale. Hence it is not surprising that large DCs can achieve a magnitude of 50,000, 75,000 sqm or even more. Whereas regional distribution centres can go beyond the threshold of $100,000 \mathrm{sqm}$, large-scale or nationally oriented facilities are likely to exceed even that. This property of modern DCs raises many conflicts in terms of land use planning, infrastructure provision and the environment. Such large facilities can hardly be placed in traditional 'gateway' regions, and certainly not within core urban areas.

The changing functional profile of the new facilities implies new locational requirements. Following the modern imperatives of mobility and accessibility, distribution firms necessarily locate at those places that offer excellent transport conditions. Secondly, they need cheap land for their increasingly large facilities. Most firms are taking into account these two particular considerations once they are looking for locale. This is due both to flow and stockkeeping aspects, regarding the high amount of freight traffic generated by DCs and their extraordinary demand for space. Trade offs between inventory and transport costs appear to be predominant, since freight transport and land use are closely intertwined (Ericksson 2001; McKinnon 1988, p. 152; Ryan 1999). Once transport markets became deregulated, total costs could be lowered by centralised locations, at the expense of higher transport costs. Final location decisions are made with respect to the network composition (i.e. the number of DCs) and the size of the markets that have to be served (Daskin \& Owen 1999), both dependent on the type of industry or product group. Evidently, locational assets are not provided for without public policy and governance, even in a globalised, apparently unbound market economy. Zoning, economic development incentives, infrastructure provision and last but not least a qualified workforce remain important location factors.

\section{LOGISTICS REAL ESTATE MARKETS AND ACTORS}

Traditionally, logistics real estate was a mere subsidiary of commercial or industrial real estate markets, different from retail or office markets but not to a large extent. Following the rise of the logistics, the real estate industry is now specialising, in order to better meet the demand of distribution businesses. Besides market growth and changing user requirements, this diversification was primarily based on two things. First, this subsector is characterised by a high market capitalisation: prime yields reach a level of eight per cent per annum, which compares very well with retail investments. Consequently, capital markets develop a rising interest in logistics real estate. A second issue that raised an increasing interest in logistics real estate was associated with the expected explosion of electronic commerce (e-commerce) in the late 1990s. With the advent of the Internet as a universal communication mode, online merchandise appeared to be a source of accelerated growth in trade and transactions. Since most of the electronicallytraded goods require physical delivery, logistics gained much interest as a tool for online-retail and wholesale. In this respect, logistics was considered a 'backbone' of the 'New Economy', without which any of the new businesses could not successfully operate. More recently, this prediction came true when e-commerce firms went bankrupt, due to their neglect of basic distribution expertise, cost and requirements.

Not surprisingly, an increasing number of studies on the emerging logistics real estate market emphasised the significance of the new market segment (Bankgesellschaft Berlin 2001; Jones Lang LaSalle 2001a, b; CB Richard Ellis 2001; HVB 2001). This is particularly based on the generic growth of the logistics market, new geographical patterns and locational strategies as an outcome of logistics consolidation, and the fact that demand for qualitative space creates the need for further development which is certainly interesting for real estate firms. The market reflects changing behaviour patterns on both demand and supply sides: The demand side consists of distribution firms in wholesale, retail and the transport industry. Their attitude to real estate is characterised by changing purposes (e.g. contract-related instead of firm related), by a changing timeline for use (short-term cycles instead of long-term) and by a changing market behaviour (lease or rent instead of ownership). Due to the rise of contract logistics as an outcome of outsourcing and periodical 
Table 1. Changes in the development of warehousing space.

Traditional development pattern

Ownership rate averages $50 \%-70 \%$

Primarily German/local firms (KG, GbR, GmbH)

Few speculative developments

Lease or rent contracts of 10 years

Weak investment market (i.e. in the case of short-term leases)
Modern development pattern

Increasing share of rent and lease

International developers and investment trusts

Speculative development of logistics parks on

significantly larger lots

User demand of 3-5 years

Strong investment market for new developments

Source: own, modified after Jones Lang LaSalle (2001a).

tendering by manufacturers or retailers, distribution firms are increasingly making flexible location decisions. The company is no longer committed to life-long location but follows the ever-changing pattern of contractional flows. Thus, locations are becoming adjusted to the temporary nature of contracts. Related operation and planning horizons appear much shorter than before, comprising three to five years (or even less) instead of up to ten years before. This also implies a different purchasing behaviour, since such firms are less inclined to buy land. As a result, rent and lease is being favoured by European logistics firms.

Significant shifts on the supply side are associated with the emergence of specialised developers and real estate brokers. Since sites and facilities are no longer user-owned, there is a bigger role for intermediaries such as development and brokering firms. Brokers trade sites in order to find customers, or they are asked by customers to seek appropriate locations. Developers purchase, own, develop and rent out land for distribution and related purposes, and also trade facilities. Both the brokers' and developers' activities emerged out of their general commercial and industrial experience, which is now being directed towards the particular demand of distribution firms - either by opening up specialised branches or by founding new firms. Many of them are global, often owned by major US corporations. Also, investment trusts and banks are increasingly becoming active in the logistics sector, in order to provide resources by capital funds. The specifics of each development pattern are included in Table 1.

An interesting German case is demonstrated by Viterra, a real estate and service enterprise that was created in 1999 by the merger of the housing subdivisions of two German industrial corporations (Raab Karcher AG and VEBA Immobilien AG). Viterra is now a wholly owned subsidiary of the EON Group and, based on self-assessment, Germany's largest property owner. In the year 2000, Viterra purchased eight logistics centres of the Deutsche Post World Net (DPWN), Germany's largest logistics firm. DPWN operates a total of 33 freight centres in Germany for parcel distribution. The eight freight centres bought by Viterra were leased back to DPWN or its subsidiary Danzas on the basis of long-term contracts. Viterra functions not only as the owner of the facilities but also as maintenance and service provider. This indicates that the outsourcing of services is now also practised in the process of site selection, development and management.

In order to evaluate the consequences of these changes: What does the emergence of brokers, developers and investment funds in the distribution business mean for regional development? First, according to an institutional view on property development (Guy \& Henneberry 2002), the changing institutional framework is likely to shape the way land devoted to logistics is becoming a commodity (see Figure 1). This characteristic is by no means new. Yet, potential distribution sites are now being assessed and traded in a completely new way. From the developers' perspective, the first and foremost goal is to achieve a revenue on the invested, instead of providing the conventional 'public goals' related to freight transport. In this respect it makes a difference whether logistics firms, e.g. SMEs, are going to build facilities for their own use and at their own risk, or whether investment companies are going to supply an anonymous market, following more or less speculative 


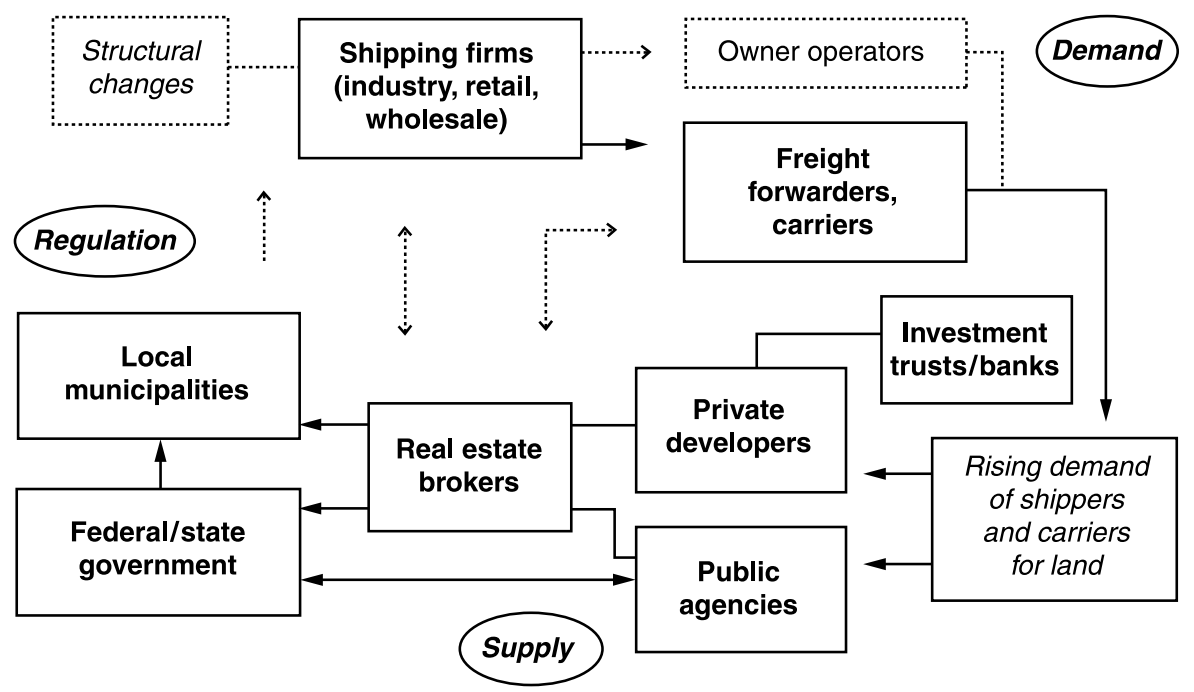

Sourece: author.

Figure 1. Actors in the system of logistics land development in Germany.

purposes. The performance of the US warehousing market is in this regard different from Europe. It is characterised by a higher degree of rent or lease (instead of ownership), by intermediate activities and speculative development of land. The consequence is more speculation is likely to increase the consumption of open space.

Second, from the service providers' perspective, the criteria for location choice are increasingly becoming multifaceted, particularly with the rise of large-scale network configurations as the overarching structure for corporate logistics strategies. Besides specific product and customer related requirements, scale and composition of the distribution network appear as decisive for the question where to locate a DC. This is particularly true for the upcoming trans-European distribution networks that are designated to serve the populated core of Eastern and Western Europe (Hoppe \& Conzen 2002). According to the concentration in the distribution industry, most of the network related siteselection is based on the active participation of brokers and developers. Once the spatial scale increases, such commodification of land leads to a certain 'abstraction' from the concrete place, in favour of the network structure. As a consequence, the network tends to determinate the node as a single local entity. This also means that local criteria, e.g. the adaptability of the node, are being outweighed against the overall network structure.

\section{LAND FOR LOGISTICS: TWO CASE STUDIES}

The rising significance of intermediaries is important for the way land is politically regulated, especially locally. Regarding the recent trend towards privatisation of infrastructure provision, this type of land development raises serious conflicts between private and public goods and interests. Market capitalisation and returns on investments are now becoming preferred in land use decisions, whereas public institutions - obligated by environmental, transport or community needs - are losing influence. Thus, a power shift in land use conflicts occurs, likely to exert an increasing pressure on public policy to open up land for development. In order to exemplify this hypothesis, two cases in the Berlin-Brandenburg region have been investigated.

The regional framework in Berlin-Brandenburg, Germany - The Berlin-Brandenburg Metropolitan region is characterised by a fundamental political and economic transformation since 1990, associated with a spatial reconfiguration. The fall of the Iron Curtain was followed by a 
Table 2. Berlin-Brandenburg - prime rents for office, service and warehousing space (euros per sqm/month), sales prices for commercial sites (euros/sqm).

\begin{tabular}{lcccr}
\hline & $\begin{array}{c}\text { Office Space } \\
\text { Rents }\end{array}$ & $\begin{array}{c}\text { Service } \\
\text { Space Rents }\end{array}$ & $\begin{array}{c}\text { Warehousing } \\
\text { Space Rents }\end{array}$ & $\begin{array}{r}\text { Sales prices for } \\
\text { commercial sites }\end{array}$ \\
\hline City of Berlin & $5-8$ & $6-7.5$ & $2.5-6$ & $125-300$ \\
Urban fringe & $5-8$ & $6-7.5$ & $2.5-6$ & $50-150$ \\
Business parks & $8-11$ & $7-8$ & $5-6$ & $150-200$ \\
\hline
\end{tabular}

Source: Jones Lang LaSalle (2001c), p. 5.

massive de-industrialisation, one cause of which was the immediate suspension of government subsidies for industries in both parts of the city. After a decade of extensive recovery and redevelopment (associated with a high level of construction and related logistics), the city of Berlin functions as the capital of the Federal Republic, as a desired centre of excellence in media and sciences, and as a large consumer agglomeration. Due to the lack of its own industrial basis, city and region represent freight destinations rather than places of origin. The exchange of goods between the Berlin-Brandenburg area and other regions is still uneven, since the import/ export ratio is $1.7: 1$ (Hesse forthcoming).

In order to cope with an expectedly high volume of freight traffic, the city senate developed an integrated policy to improve the efficiency and the acceptability of urban distribution. The policy scheme was jointly developed with the state of Brandenburg and comprised the establishment of dedicated freight centres, the optimisation of inner-city distribution and the organisation of a particular construction logistics at major building sites in the city centre. Freight transport, trucking and warehousing firms were attracted to locate in three freight centres. So the proto-typical suburban shift of distribution firms is not only due to locational advantages and land prices, but also an immediate product of subsidies and policy (see Table 2). Besides the freight centres, further commercial development happened along the southern backbone highway and the Berlin beltway autobahn in general, with distributive services (logistics, wholesale, retail) almost predominant and core manufacturing mostly absent.

Land development by public agency: the integrated freight centre (IFC) ${ }^{1}$ - Three large integrated freight traffic centres in the BerlinBrandenburg region have been opened up since the mid 1990s, located at the eastern, southern and western urban fringe about 35-40 kilometres from the city centre (see Figure 2). The freight centres were established at three strategic places close to motorway intersections. Such locations at the southern fringe, in a western and a northeastern corridor are remote but easily accessible from both directions (city, beltway) and thus highly attractive for distribution firms.

The function of the IFC is threefold: to procure large, accessible sites for locating freight transport, freight forwarding and warehousing firms, and to offer proper operating conditions without affecting sensitive neighbourhoods. By locating different firms of the same sector close to each other, linkages and agglomeration benefits are hoped for (see McCalla et al. 2001). Second, IFC will contribute to the transshipment of road haulage to railways and waterways, particularly for long distances. Hence, multimodal infrastructure is supplied. Third, the final goods supply into the denser urban space will be more acceptable, sustainable, with smaller delivery vans instead of heavy vehicles (Senatsverwaltung für Stadtentwicklung 2000). The three IFCs represent typical suburban centres in large areas with substantial space requirements. Since freight companies are weak competitors on the land market, these space requirements might not be fulfilled within the core urban areas or without particular planning provisions. Each location was zoned for commercial or industrial land use, allowing for 24-hour operations. Transport infrastructure is provided with respect to motorway access and newly constructed trunk roads.

The IFC implementation in Berlin-Brandenburg is mostly advanced among such concepts in 


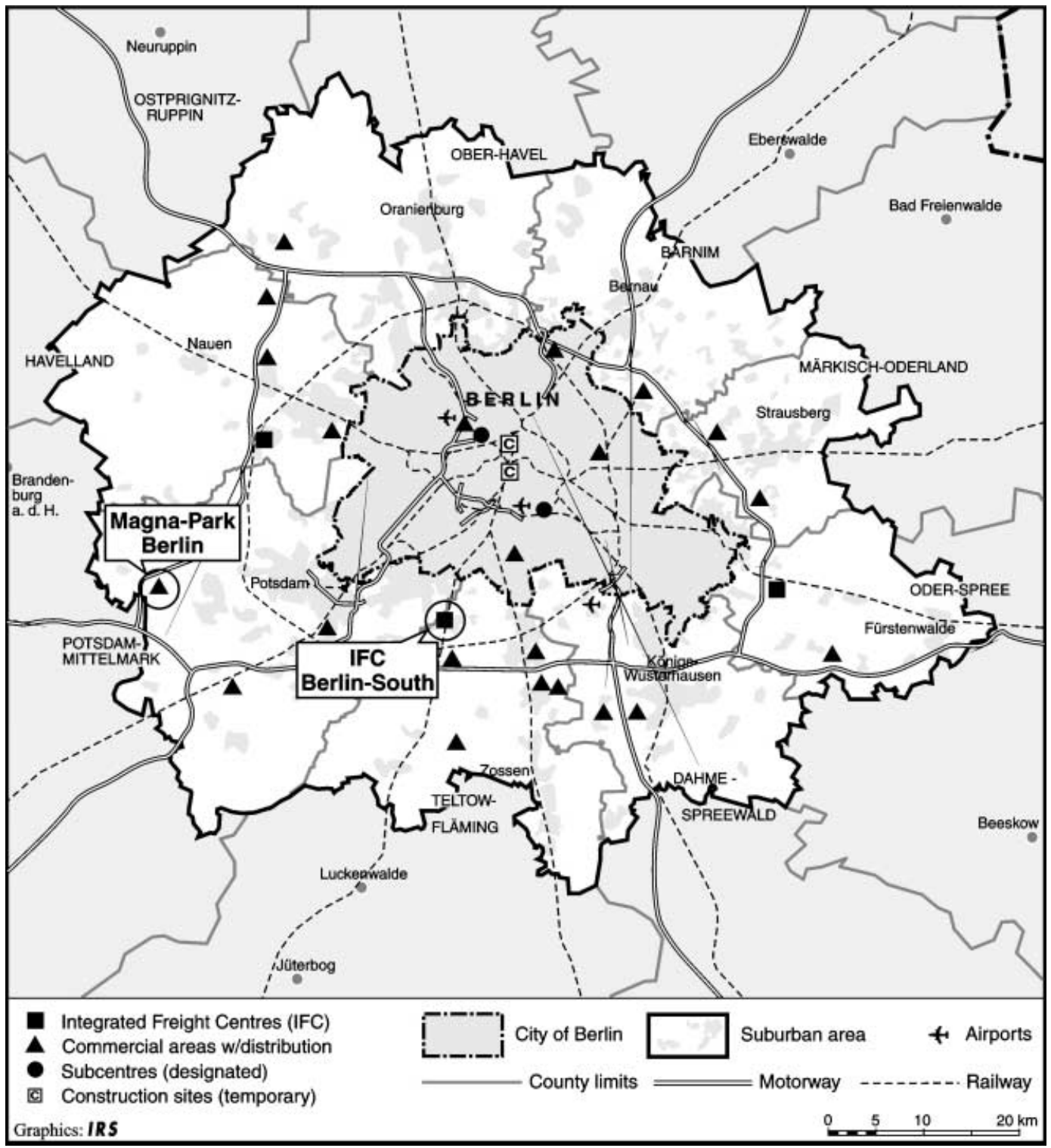

Figure 2. Berlin-Brandenburg metropolitan region.

Germany. Meanwhile, a notable number of companies were attracted to buy lots and to locate at the freight centres. In April 2002, about 85 enterprises were located within the IFC, which created approximately 4,800 jobs (some of course just shifted there); federal and EU-subsidies of about 86.7 million euros have been spent in order to secure public goals. About two thirds of the lots were settled, the remainder is expected to be sold over the next few years. Thus, the IFCs represent regional 'distribution complexes' and host many space consuming firms. Yet, the practical impacts of the freight centres still remain unclear. There are substantial contradictions and conflicting aims between two major targets: supply of land and optimisation of freight transport. This is due to the implementation process under market 
conditions. Site development and the construction of terminals take years to complete. Final success depends on market demand: IFC development occurs within a competitive market environment, since freight sites have also been established outside IFC areas. The publiclyowned IFC sales and marketing firm must find buyers or tenants for the properties, and dependent on the demand, they are often inclined to accept any firm that buys a lot. This 'logic of utilisation' undermines the goal to keep out such enterprises which are not suitable for IFC locations, like handicraft firms. Second, it is unlikely that special requests are being addressed to operators, e.g. to use intermodal facilities or to co-operate with other enterprises. Following usual market conditions, the vast majority of freight transshipped through the IFC belongs to road transport. ${ }^{2}$ This is certainly a response to competition and low freight rates, both favouring the market position of road haulage firms.

Finally, IFC operations can have conflicting impacts on either long-distance or suburban traffic. This hardly permits a general judgement of the effects, yet. IFC are often likely to support more efficient long distance operations, at the expense of increasing local transport. Thus, the total result in terms of traffic generation or reduction can often favour the first (cf. Sonntag et al. 1998). IFC development turns out to have uncertain effects, opening only few windows of opportunity for planning and policy, since freight centres are subject to market conditions, particularly competition among land developers and freight operators. In this regard, they do not necessarily work as a policy tool. The firms' delivery operations remain under their own control, hardly being managed by a supply side oriented policy only. The more strongly IFC development is regarded mainly in economic terms (by freight operators and municipalities), the smaller is, however, the chance for accomplishing planning targets.

Land development by private real estate enterprise: the 'Magna Park' project - Whereas the state of Brandenburg and its development agency proceed with further acquisitions for the three existing IFCs, in order to add critical mass to the centre and to gain returns on the infrastructure investments, greenfield development is still underway. One of the most significant examples is the 'Magna Park' near the small town of Werder (Havel), 40 kilometres west of Berlin. The developer is Gazeley Properties, a UK firm specialised in logistics and warehousing space. Gazeley is a subsidiary of the US retail chain WalMart and owns a land bank of about 650 hectares at 13 sites in Europe, mostly in Great Britain (Gazeley UK corporate information 2002). Gazeley is now increasingly active on the continental market, the Berlin Magna Park being the first such project, to be followed by developments in Spain, Italy and Poland eventually. The competitive advantage pursued by Gazeley belongs to speed in development: 'Fast track development' promises to realise fully fitted, racked warehouses within 16-20 weeks (Gazeley UK corporate information 2002).

Excellent traffic access at the intersection of the A10 motorway and the B1 trunk road was one of the main reasons for Gazeley to select the site, besides proximity to Berlin and cheap space available. The site is 50 hectares large and will finally host 200,000 sqm of distribution and warehousing space. The first two buildings, out of total 19 projected, were completed by the end of 2002. The development is worth about 150 million euros and is purely speculative: the two existing facilities with a capacity of about 7,000 and 12,000 sqm are still empty. A real estate brokering firm was hired to promote the site and to seek clients. Different from the IFC, the Magna Park does not provide any specific freight traffic assets, besides a gas-station.

The developer decided not to settle within one of the freight centres, as it was preferred by regional planning and IFC development. Gazeley decided to locate farther away and close to the motorway, probably due to the location factors named above, to legal conformity of the project (which appears to be decisive for 'fast track') and to low land costs, even compared with the subsidised lots in freight centres. The 'external' implications are clear: the site is consuming dozens of hectares of open space, whereas the public agency is under pressure to sell vacant but fully developed land in the IFC - even to non-logistics firms, in order to receive any return on the invested capital. Second, logistics operations at Magna Park will generate lorry and parcel van movements exclusively, 
thus contributing to freight transport growth and adding to the region's traffic problems. Concerns about transport related noise emissions were considered 'entirely arbitrary' by the developer, since lorries would solely use the motorway network; this statement does not really make sense, since proximity to Berlin as the most important location factor will indeed cause a certain amount of regional traffic aside from the Berlin beltway. The Magna Park site is also poorly integrated in terms of urban planning - a typical case of urban sprawl that regional planning actually wanted to avoid.

In the light of this criticism, why was the project created, how was it approved by local and regional planning authorities? First, the project is based on a building permit from 1990, the early days of German unification and six years prior to the inauguration of the 'BerlinBrandenburg Joint Planning Agency'. This delay of putting regulation into place is mainly responsible for a large number of scattered, outof-town greenfield developments in the region. In the Magna Park case, there was no need for new zoning, since the site had already been dedicated to distribution purposes. Gazeley then applied for a new building permit which had to comply only with the changing building content. After extensive negotiations with the municipality, Gazeley received permission to develop the site in February 2002. Second, Gazeley promised to foster local economic development by creating 1,500 jobs, which is the most convincing argument for such projects today. State ministries and regional authorities of the almost bankrupt states of Berlin and Brandenburg are currently inclined to sanction almost any investment in search for job creation and tax spending. Third, the logistics sector is increasingly sold to the public as being 'modern', with the premise of technology, competitiveness and transport knowledge. This image is highly constructed, since the industry is facing competitive challenges and has not yet yielded massive employment gains. It also contrasts with the mere incidence of physical distribution in the shape of truck traffic, warehouses and often low-wage jobs.

The positive images associated with the establishment of Magna Park are rather ironic, since the development is purely speculative. Nobody knows who is going to occupy the site, for what purpose (more flow- or more stock-oriented) or how large the workforce might be. Whereas this seems to be the case in many development issues in general, speculative projects embody this trait in a particular way. In assessing the Magna Park project, the local municipality has been completely dependent on statements of the developer, whether they were credible or not:

Well, we cannot tell you details on the significance of the site, e.g. in terms of traffic and logistics aspects, since in this respect we completely rely on the information given by the investor. They told us that 'Magna Park' will function as a node within a trans-European network. As a consequence, transport flows may not really touch the region. There might be a handful of parcel vans going into and out of the site, but we expect this will not be really important. (Research interview, City of Werder, November 2002).

Consequently, local authorities did not require certain standards of environmental compliance or traffic optimisation once the building permit was given. On one hand, the hope for substantial job generation through the investment obviously appears as the overarching motive for city officials to approve the project. On the other, the relatively high level of regional planning tends to run out, not only for historical reasons (the old building permit), but also due to its limited ability to manage local competition. It is also ironic that environmental considerations are not fully disregarded by the developer. Gazeley was presented in the local press as 'specialised in sustainable distribution centres' (Märkische Allgemeine 6 October 2001), announcing that their high-quality design standards would include environmental aspects: 'Gazeley has planted . . . over 1,000 trees and bushes to provide a natural habitat for numerous types of wildlife' (Gazeley UK corporate information 2002). The Berlin Magna Park site can thus be distinguished from ordinary logistics areas, since it is landscaped and has an unusual, white/blue-coloured facility design. Yet the reason for painting the buildings is merely economic: they will draw attention from drivers on the adjacent motorway and thus advertise the location. 


\section{CONCLUSION: THE MEANING OF LOGISTICS REAL ESTATE FOR POLICY AND PLANNING}

The upcoming logistics real estate markets indicate current spatial dynamics and reflect the changing socio-economic framework of logistics and distribution. Whereas much attention has been paid in the past to flow-related aspects, particularly in the context of global trade, considering real estate markets emphasises the often-neglected land-use implications of distribution. The latter was the core subject of this paper. In order to generalise some findings, the projects presented in the case studies above are characterised by different development patterns. These differences do not only belong to location and infrastructure, but also to institutional dimensions of the development process, particularly the planning concept, firms and agencies involved, and the degree of regulation (see Table 3 ).

New land demand-and-supply-patterns affect regions in two ways: First, new players emerge on the real estate market, highlighting land capitalisation and competition, but disregarding urban planning and integration issues. The speculative nature of development activity raises land consumption and contributes to urban sprawl. Distribution firms particularly apply to this, since the comprehensive 'orchestration' of material flows requires not only new sites but also extensive infrastructure, to connect interrelated places. Such prevalent commodification of land attracts further growth and agglomeration. Thus, distribution takes over the classic role of industry in shaping the territorial organisation: it 'produces' places (Storper \& Walker 1989, p. 70). As a result, 'regional complexes of distribution' emerge, places dedicated to the handling of goods, either being isolated (DC) or, whenever that is the case, more integrated (IFC).

Second, whereas infrastructure provision was once a predominantly public task (at least in Germany), it is increasingly becoming subject to private corporate decision-making. As a consequence, policy goals become more difficult to achieve: competitive dynamics between firms and - particularly - between municipalities do not allow for setting standards or demand commitment, etc. The more speculative the nature of development, the more contingent planning will be. Third, even ambitious public agency plans do not necessarily ensure the achievement of public goals. This is due to the market imperative of acquiring firms and selling land - goals that must be respected by public development bodies as well, at the risk of their own failure. Aims other than land development, like promoting intermodal freight transport, may not be pursued to the same extent. Speaking in general terms of policy and planning, it appears that the power relations between public and private actors are further shifting towards the private.

Cities and regions are particularly affected by these changes, since the geographies of distribution are based upon newly emerging nodes within large-scale networks (Amin \& Thrift 1992; Smith 2001). These nodes are physically grounded in urban and metropolitan places, thus representing a certain 'spatial fix' of logistics. Yet, the two case studies also reveal a shrinking local embeddedness of modern sites, since firms try to get rid of traffic jams, the rigidities of planning requirements, or the power of trades unions - factors that are more prevalent within urban regions than at their periphery. Thus, changes in distribution have material

Table 3. Public and private development in comparison.

Integrated freight centre
Magna Park

\begin{tabular}{lll}
\hline Development & Policy oriented (transport, economic development) & Capital oriented \\
Occupier firms & Logistics, distribution, related services, others & Logistics, distribution \\
Major players & Public agency (state-based), local municipality & Private developer (international) \\
Contracts & Lots for sale & Rent or lease \\
Location & Partly integrated & Isolated \\
Traffic access & Multimodal (road, rail, partly water) & Road traffic
\end{tabular}

Source: authors research. 
implications for planning and policy. The most urgent need is establishing a general awareness of the distribution economy. Furthermore, public sector actors should focus on two things. First, the current most competitive road-based distribution should be considered an important subject to local and regional planning. This should happen as early in the development process as possible, particularly regarding three questions:

1. How can logistics requirements become integrated in long-term planning objectives (land use, regional development)?

2. How can the decision where to locate DCs and warehousing be better balanced in future?

3. How can the distribution operations be organised more acceptably for the community, e.g. by establishing dedicated lorry routes or by minimising neighbourhood conflicts?

A second consideration is the market potential of the intermodal warehouse or DC. It was traditionally located in port cities, in old industrialised areas with a high share of manufacturing or in the core commercial area of urban regions. The intermodal DC may play an important role in future distribution, since it offers options to overcome capacity - and acceptability - constraints at other locations. If transport access is becoming a scarcity, traditional locations could gain a higher share of the distribution market. There is also potential for the conversion of military sites, e.g. railyards or regional airports, in order to establish new multi-modal facilities (Haywood 2001; StraussWieder 2001). Implementing such policy goals is the joint responsibility of private and public actors, the more dominant private interests appear. Regarding the emergent role of brokers and developers in the process of 'grounding' distribution, it is becoming increasingly important to make them aware of the generic significance of their product. Internalising the transport externalities of distribution sites can be regarded as an 'environmental innovation' (Guy 2002, p. 247) that should be incorporated in the social organisation of the property business.

\section{Notes}

1. This section refers extensively to a case study on the Berlin-Brandendurg Freight Policy Concept by the author (Hesse, forthcoming).
2. In 1999 , only 5,000 tonnes out of 4.7 million tonnes were shipped via rail (Landtag Brandenburg 2000). The intermodal terminal in the IFC Berlin-West is currently out of operation, previously used for parcel container shipments. The intermodal terminal in the IFC Berlin-South has hardly been used so far, the railway infrastructure in the IFC-Berlin East has not been used at all.

\section{Acknowledgements}

This paper is based on research supported by the German Research Organisation (DFG) and the Free University of Berlin, Department of Geography. I am indebted to comments on earlier versions given by Richard A. Walker (UC Berkeley, California) and Andrew Goetz (University of Denver, Colorado).

\section{REFERENCES}

Allaert, G. (1999), The iron Rhine, key issue for cross bordered development. Paper presented at the 1st Scientific Euregional Conferences (SEC), Maastricht 17-18 November.

Amın, A. (1999), An Institutionalist Perspective on Regional Development. International Journal of Urban and Regional Research 23, 366-378.

Amin, A. \& N. Thrift (1992), Neo-Marshallian Nodes in Global Networks. International Journal of Urban and Regional Research 16, 571-587.

BANkgesellschaft Berlin (2001), Logistikimmobilien. Immobilienmarkt-Research. Marktbericht 8. Berlin, Juli 2001 (Bearb.: Gewos-Institut für Stadt- Regional- und Wohnungsforschung $\mathrm{GmbH}$ ).

Bowersox, D., E. Smykay \& B. LaLonde (1968), Physical Distribution Management. Logistics Problems of the Firm. New York/London: MacMillan.

Chapman, K. \& D. Walker (1991), Industrial Location. 2nd edn. Oxford, Cambridge: Basil Blackwell.

Chinitz, B. (1960), Freight and the Metropolis. The Impact of America's Transport Revolutions on the New York Region. Cambridge, MA: Harvard University Press.

CB Richard Ellis (2001), Logistik- und Distributionszentren in der Bundesrepublik Deutschland. Frankfurt am Main, May 2001.

Daskin, M. \& S. Owen (1999), Location Models in Transportation. In: R.W. HALL, ed., Handbook of Transportation Science, pp. 311-360. Boston/ Dordrecht/London: Kluwer Academic Publishers.

De Ligt, T. \& E. Wever (1998), European Distribution Centres: Location Patterns. Tijdschrift voor Economische en Sociale Geografie 89, 217-223. 
Dicken, P. (2003), Global Shift. 4th edn, New York: Guilford.

Ericksson, T. (2001), Urban Freight Economics: A New Rail Paradigm For Large Lots. Transportation Journal 40, pp. 5-15.

GAZELEy, UK (2002), Corporate information, retrieved from http://gazeley.com on 19 November.

Glasmeier, A. \& J. Kibler (1996), Power Shift: The Rising Control of Distributors and Retailers in the Suppy Chain for Manufactured Goods. Urban Geography 17, 740-757.

Guy, S. (2002), Developing Interests: Environmental Innovation and the Social Organisation of the Property Business. In: S. Guy \& J. Henneberry eds., Development and Developers Perspectives on Property 247-266, Real Estate Issues Series. Oxford/UK, Malden/MA: Blackwell Science.

Guy, S. \& J. Henneberry eds. (2002), Development and Developers. Perspectives on Property.

Hayter, R. (1997), The Dynamics of Industrial Location. The Factory, the Firm and the Production System. Chichester: Wiley.

Haywood, R. (2001), Rail-freight Growth and the Land Use Planning System. Town Planning Review 72, pp. $445-467$.

Hesse, M. (2002), Missing Links: Geographies of Distribution. Unpublished paper, presented at the 2002 AAG-Annual Conference, Los Angeles/ California, March.

Hesse, M. (forthcoming), Logistics and Freight Transport Policy in Urban Areas. A Case Study on Berlin-Brandenburg/Germany.

Hoppe, N. \& F. Conzen (2002), Europäische Distributionsnetzwerke. Munich: Gabler.

HVB/HyPOVEREINSBANK (2001), Immobilienmarktanalyse: Lager und Logistik Berlin. Munich, October 2001.

Jones LANG LASALle (2001a), The Changing Landscape of European Distribution Warehousing. January 2001.

Jones Lang LaSAlle (2001b), European Real Estate, Key Market Indicators. Q4.

Jones Lang LaSAlle (2001c), Gewerbegebiet Report Berlin. Der Markt für Büro-, Industrie- und Gewerbeflächen in der Region Berlin. Berlin, April.

Landtag Brandenburg (2000), Antwort der Landesregierung auf die Große Anfrage der PDSFraktion 3/1652 vom 29.8.2000. Potsdam.

Marshall, J.N. (1988), Services and Uneven Development. Oxford: Oxford University Press.

McCalla, R., B. Slack \& C. Comtois (2001), Intermodal Freight Terminals: Locality and
Industrial Linkages. The Canadian Geographer/Le Géographe canadien 45, pp. 404-413.

McKinnon, A. (1983), The Development of Warehousing in England. Geoforum 14, pp. 389-399.

McKinnon, A. (1988), Physical Distribution. In: J.N. Marshall ed. Services and Uneven Development, pp. 133-159, Oxford: Oxford University Press.

McKinnon, A. (1998), Logistical Restructuring, Freight Traffic Growth and the Environment. In: D. BAnister, ed. Transport Policy and the Environment, pp. 97-109. London: FN Spon.

Pellegram, A. (2001), Strategic Land Use Planning for Freight: The Experience of the Port of London Authority, 1994-1999. Transport Policy 8, pp. 11-18. Riemers, C. (1998), Functional Relations in Distribution Channels and Locational Patterns of the Dutch Wholesale Sector. Geografiska Annaler 80 B, pp. 83-97.

Ryan, S. (1999): Property Values and Transportation Facilities: Finding the Transportation-Land Use Connection. Journal of Planning Literature 13, pp. 412-427.

Senatsverwaltung für Stadtentwicklung (2000), Stadt und Verkehr. Planungsansätze zur Integration 1995-1999. Berlin.

SMith, M.P. (2001), Transnational Urbanism. Locating Globalization. Malden/MA, Oxford/UK: Blackwell. Sonntag, H., B. Meimbresse, W. Eckstein \& J. LATTNER (1998), Städtischer Wirtschaftsverkehr und logistische Knoten. Wirkungsanalyse von Verknüpfungen der Güterverkehrsnetze auf den städtischen Wirtschafts- und Güterverkehr. Final Report. Berlin and Bremen.

Storper, M. (1997), The Regional World. Territorial Development in a Global Economy. New York, London: Guilford.

Storper, M. \& R. WALker (1989), The Capitalist Imperative. Territory, Technology and Industrial Growth. New York/Oxford: Basil Blackwell.

Strauss-Wieder, A. (2001), Warehousing and Distribution Center Context. NJPTA Brownfield Economic Redevelopment Project. Prepared for the New Jersey Institute of Technology and the North Jersey Transportation Planning Authority. February.

van Klink, H. \& G. VAN DEN Berg (1998), Gateways and Intermodalism. Journal of Transport Geography 6, pp. 11-19.

VAnce, J.E. (1970), The Merchant's World. The Geography of Wholesaling. Englewood Cliffs, NJ: Prentice Hall. 